\title{
IMPROVING SPEAKING ABILITY BY USING SHORT MOVIES AT ELEVEN1TH GRADE STUDENTS OF SMA NEGERI 5 PALU
}

\author{
Agus Laiya \\ Nur Asmawati \\ Andi Muhammad Dakhalan \\ English Tadris Department, Teacher Training And Tarbiyah Faculty \\ State Institute of Islamic Studies \\ Email: agusslaiya27@gmail.com
}

\begin{abstract}
This paper focuses on the application of short movies as a media in improving speaking ability at eleventh grade students of SMA Negeri 5 Palu. The researcher applied quasi experimental research design which involved two classes of students, they were experimental class and control class. The instruments of data collection were pretest and posttest. The pretest was used to measure prior knowledge of the students and the posttest was used to measure the development of the students' knowledge after the treatment. The ttest was analyzed to compare the mean scores of both classes. There is a significant difference score of the experimental class (1940) and the control class (1490). The level of significance was set up at 0.05 with 58 degree of freedom $(\mathrm{df}=29+31-2=58)$. The result of data analysis indicates that $t_{\text {counted }}(6.84)$ is higher than $t_{\text {table }}(2.002)$. It means that the hypothesis is accepted. Thus, the use of short movies can improve students' speaking ability at eleventh grade students of SMA Negeri 5 Palu.
\end{abstract}

Keywords: Improving; Speaking; Short Movies. 


\section{Background}

In Indonesia, English has become one of few foreign languages (Germany, France, Japan, Arabic and Mandarin) which is studied at school. It is indicated by the phenomenon that English in Indonesia is studied in formal setting. English is taught as a compulsory subject in junior high school, senior high school, even in university levels to acquire certain four language skills, there are Speaking, Writing, Listening, and Reading. Taking a deep concern on global competition where English competence is necessarily needed. Government which takes responsibility for education field has included English as one of subjects tested on the National Exam.

In SMA Negeri 5 Palu English skill of students are considered, one of which is the speaking skill of students. They are required to practice speak English during teaching and learning English. In speaking learning in the class, teachers ask the students to make dialogue and practice in front of the class. But, in fact still many students that not well to speak English. Because, many students do not enthusiastic during the teaching and learning process.

Speaking is part of the language skills which is important for language learners to be develop, it is also regarded as essential skill for undergraduate students since it will show that the students are mastering English. Furthermore, as foreign language learners, we should master speaking skill in English as our priority. ${ }^{1}$ Because, when someone speaks, they are performing their other skills such as their listening skill, vocabulary, understanding of

1 J.C. Richard, Teaching Listening and Speaking : From Theory to Practice. (New York: Cambridge University Press, 2008).
English sentences, pronunciation, articulation and so forth.

Thornbury stated that in the nature of speaking, speakers do some important parts to express their intentions. They should deal with speech production and self-monitoring, articulation of their words and should manage their talk accurately and fluently. ${ }^{2}$

In the other cases, people conducted speaking to express what is on their mind and what they want their listener do for them. It can be stated that through speaking, speaker expressed their thought and what they felt, argued an issue in which the speakers tried to affect their listener. So that's speaking is the part of communication that really important to be used to communicate with other people to make them understand what we talk. ${ }^{3}$

Based on the interview with English teacher and some students of the eleventh grade students of SMA Negeri 5 Palu, teaching learning process did not run well because of some problems. The problem is the students shy to spoke English because their pronunciation was bad and worried if they were making mistaken. Other Problems, the students feel bored if situation in the class is monotones because there is no new situation and students feel difficult to improve their speaking when the strategy just like conversation or dialogue, the teacher often instructs the students to memorize the words without looking at the context and also the teacher gave the formula of grammar and the students

2 S Thornbury. How to Teach Speaking. (England: Longman, 2001), 5.

3 Nurdin, N. (2009). Segregasi Dalam Pengajaran Dan Penguasaan Bahasa. MUSAWA, 1(1), 23-41. 
memorized it. It made the students got difficult to remember all of those and the students got some problems to use those as speaking target. It was caused by the method applied by English teacher still seems traditional. It was known that there was no best way to learn and there was no best strategy to solve the students' problems. However the teachers can apply one of some relevant approaches by considering the students' condition.

Based on the phenomenon, the researcher was interested in applying short movies as the alternative medium to solve the problem. Movies can take their attention by the audio and visual from the movies, and they learned about the culture, knowledge, and knew how native speakers pronounce the words and also they got the new vocabularies that unusual in Indonesia. As Lynch stated that, There are five reasons why movie is used as teaching media, they are varieties of accent can be demonstrated, slices of culture can be demonstrated, historical change can be easily demonstrated, using audiovisual element\$) aids learning, and movies are great to watch. ${ }^{4}$

For the reason above, the researcher wants to prove how short movies as the medium can enhance students' speaking ability, and it can encourage students to be more active in speaking. So, the researcher interested in conducting a research entitled:

"Improving Speaking Ability by Using Short Movies at Eleventh Grade Students of SMA Negeri 5 Palu’.

\section{Literature Review}

\footnotetext{
${ }^{4}$ M. L. Lynch, 5 Ways to Use Popular Movies for English Language Teaching (Ezine Articles: diakses dari http://EzineArticles.com/?expert=Larry_M._Lynch, 2006)
}

\subsection{Definition of Speaking}

These are the explanation about speaking according to the experts, Brown defines speaking as oral interaction where the participants need to negotiate meaning contained in ideas, feeling and information, and manage in terms of who is to what, to whom an about what. ${ }^{5}$ While, Harmer states speaking is the ability to speak fluently and presupposes not only knowledge of language features, but also the ability to process information and language "on the spot"6. Nunan defines speaking as the use of language quickly and confidently with few unnatural pauses, which is called as fluency. Therefore, the researcher concluded that speaking is the ability to produce the language and share their ideas, information, suggestion and feeling to the others in oral form by considering culture and social context occurred. ${ }^{7}$

a. Types of Speaking

Nunan writes that generally there are two types of spoken language, as follow: ${ }^{8}$

\section{Monologue}

According to Brown, monologue is the speaking where one speaker uses spoken language for any length of time, such as in speeches, lectures, readings, news broadcasts, and the like, then the listener have to process the information without interruption and the speech will go

${ }^{5}$ H. D. Brown, Language Assessment: Principles and Classroom Practices. (NewYork: Pearson Education Inc. Javanovich, 2003), 140.

${ }^{6} \mathrm{~J}$. Harmer, How to Teach English. (China: Pearson Education, 2007), 284.

${ }^{7}$ Kayi L, The nature of language in use. (Bandung: Tritustra, 2006), 1.

${ }^{8}$ Nunan, D., \& Carter, R. (Eds.), The Cambridge guide to teaching English to speakers of other languages, (Cambridge: Cambridge University Press, 2001), 250. 
on whether or not the listeners comprehends what the speaker means.

2) Dialogue

It is different with monologue; Nunan says that dialogue is the speaking that involves two or more speakers. The interruption may happen in the speech when the interlocutor does not comprehend what the speaker say. Like Nunan, according to Harmer finally, we might make a difference between speaking, that is planned (such as lecture or weeding speech) and speaking that is unplanned, such as a conversation that takes place spontaneously. ${ }^{9}$

\section{b. 2.2 Short Movies}

A short movies is any movie not long enough. It has running time of 30 minutes or less. The story of the short movie only has one plot. Although the duration is no longer than 30 minutes does not mean that the content of the movie will be meaningless. The short time that has had by short movie, make the researcher wants to use it as a learning media for teaching speaking. Short movie can be used to teach speaking ability. Students ask to do retelling based on the movie that they already watched. That activity will be done in experimental class. This media is expected able to make students easier toc) understand the story rather than reading text only. Since the learning type of each students is different so the researcher wants to make all of the learners are able to follow the lessons by using this media.

\section{3 eaching Speaking Using Short Movie}

Teacher needs some preparations to bring short movie as media, such as the movie that will be played, power point, laptop, speaker, and projector. As short

\footnotetext{
${ }^{9}$ Harmer, How to Teach English, 343.
}

movie will not take long times, therefore it is considered will be effective to be used. There are three steps of using short movie in teaching learning process in treatment class:

1) Previewing Activities. In this step, the teacher prepares the film and gives the students brainstorming about film.

2) Viewing Activities. This is the main step. The students watch the film and find the new vocabularies, the teacher asks some question related to the film.

3) Post viewing activities. The students are given time for speaking activity.

There are some activities that can be done by the students in teaching learning process by using short movie as media:

a) Find the new vocabularies. It means that they should pay attention to the movie and find the new vocabularies that they don't understand the meaning. After the teacher play the movie, we will discuss about the vocabularies that they got to make the same perception about that movie.

b) Playing and pausing. The teacher plays the movie and turns it off in the middle. It is aimed at making the students want to know the end of the film. The teacher asks the students to continue the story with their own interpretation.

Synopsis making. The teacher plays the movie from the beginning until the end, while the movie is playing, the students take the synopsis of the movie. In this case, the researcher will choose the third point that is, the researcher will play the movie from the beginning until the end.

although, there are some problems that will appear in using short movie as a media for example student may find difficulty to listen to the pronunciation, catch the meaning of vocabulary, and nervous to produce their idea orally. To solve those problems, the teacher can play 
the movie with pausing in each part that is needed to be paused and not too fast, show some possible vocabulary that will be met, and give high motivation to the students to be brave to try.

\section{Methodology}

This research used experimental research. Specifically, used quasi experimental design. There were two classes in this design. They were experimental class and control class. Both of the classes had pretest and posttest, but in experimental class there was a treatment that was given after the pretest, while control class there was no treatment. The design of this research is proposed by Arikunto as follows:

\section{$\begin{array}{llll}\text { Experimental class } & 01 & \mathrm{X} & \mathrm{O} 2\end{array}$

$\begin{array}{lll}\text { Control class } & \mathrm{O} 1 & \mathrm{O} 2\end{array}$

$\begin{array}{ll} & \text { Where: } \\ \mathrm{O} 1 & \text { : Pretest } \\ \mathrm{X} & \text { : Treatment } \\ \mathrm{O} 2 & \text { : Posttest }\end{array}$

The location of the research was at SMA Negeri 5 Palu, Jln. Trans Sulawesi, Kel. Tondo, Kec. Mantikulore, Kota Palu, Sulawesi Tengah.

The sample of this research are XI MIPA V class as experimental group, and XI MIPA VI Class as Control group. To obtain the data needed, the researcher administered test. The researcher chose this technique to collect the data because this technique is easy to apply to the students. The test involved pre-test and post-test. This study was taken 8 meetings, each meeting took 2 lesson hours and it need 1

${ }^{10}$ Arikunto S, Prosedur penelitian suatu pendekatan praktek (Edisi Revisi VI). (Jakarta: PT Rineke Cipta, 2006), 85. hour 30 minutes each meeting. Besides, there is 45 minutes each lesson hour.

\section{Result and Discussion}

In this research, the researcher used short movies to improve students' speaking ability because it is the interesting way to learn speaking by audio-visual. Short movie is appropriate to use for lower intermediate level students and above. It is interesting and effective to apply in teaching learning process.

The researcher chose short movies as a medium to improve students' speaking ability because the students will feel relax and enjoy because the movie is more interesting in learning English, and they can solve their problem in learning speaking because the teacher can use the suitable movies in teaching. Short movie is a medium to motivate the students to avoid the boring time into high motivation or interesting time, short movies usually work in all ages, especially for senior high school, so that in this term the researcher applied short movies as a medium to improve students' speaking ability.

The researcher found the real situation in the classroom after the researcher doing his preliminary observation. The classroom situation was boring because the students did not pay attention with the material that the teacher gave because of the method that the teacher gave seemed old. The students also hard to catch the material, it's because the teacher just asked them to do the task in handbook by no explaining but just reading and translation. Therefore, the situation made the students sleepy and bored, the result of the method that the teacher did was not effective for the students to learn this kind of foreign language.

By doing preliminary research, the researcher saw that some of the students seemed bored and did not pay attention to 
their teacher. This situation indicated the students had problem in learning English, this research was a quasi-experimental research. The researcher gave the students a pretest to both experimental and control class before the treatment applied, the result of the pretest to both classes showed that the students' speaking ability was low.

The process of instructional treatment was open by asking the previous materials. After knowing the materials which had been taught by their teacher, the researcher gave some questions related to the topics to get their attentions and also told them about the instructional objectives. To get their interest in learning speaking the researcher told them that the researcher use movie as media in teaching during the treatment. Before watching short movie the researcher explained the material about "Giving Opinion and Thought". After giving clearly explanation to them, the researcher played the movie and asked the students to observe it. It was play for about 7 minutes. In order to have better understanding about the materials that related with the short movies that the students have been watched, the researcher asked them to discuss the movie that related to their materials in English handbook. After the students discussed the movie with their friend or together with the teacher, the students should present it in front of class one by one. The researcher gave 5 minutes each student to present it.

At the first meeting in giving treatment, most of the students gave wrong explanation about the movie and some of them could not present their result of discussion because most of them in experimental class were passive students in Every meeting during the treatment, most of the students were more active than first meeting because the researcher did his role in friendly situation. In the second meeting in treatment the students still shy to speak in front of class because they were not confidence yet to show the capability in class. In the third until fifth meetings they could made theirself more active and confidence and they can speak slowly. At sixth meeting in the treatment, all of the students more active and could present their result of the discussion it means that the students could beat their unconfident situation.

Based on the result of posttest, after administering the treatments in the experimental class, the researcher concluded that it was easy for students to speak English including describing about the movie and the personages. They felt confidence while describing movie in front of the class without afraid to making mistakes. It was caused by interesting media which were amusing students who watch it. In addition, students acquired some new vocabularies, pronounced the word as well, understanding in grammar, and got motivation after watching movies.

It was happened because in the first time after the movies played, the researcher gave students chance to ask some short conversation or movement from the movies that they did not understand. Then, they asked to the researcher to repeat the conversation. After the researcher pronounced the sentences of the conversation from the movies, then the researcher asked the students to pronounce that sentences again. In the second time when the researcher played the movie, the students had a chance to write down the words that they got after watching the movie and they asked to the researcher how to pronounce the words that they did not know how to pronounce it better. At the third time the researcher played the movie, after that the researcher asked the students to make the conclusion about the movie that related to the material that researcher has 
been explain at the beginning before playing the film and present it orally in front of the class. After all of the students presented their result of the discussion about the movie the researcher fixed some discussion or sentences that were missing.

Posttest was given to the students to both experimental and control class in the sixth meeting The aimed of posttest as the researcher has explained in Chapter III that it was to measure the students' speaking ability especially in fluency and accuracy after given the treatment. The result of the posttest showed that both experimental class and control class had improvement but the progress was different. The score of experimental class in posttest was higher than the control class.

The researcher computed the mean score of students' pretest and posttest by applying the formula design in Chapter III. In the posttest the students' individual score is better than pretest in both experimental and control class. From the calculation, the researcher can interpret that the result of posttest in experimental class is higher than pretest, and it is widely that the students' speaking ability improved after giving the treatments by using short movies as a media in teaching leaning process. After that, the researcher computed the deviation score to compare the students' scores in pretest and posttest to both experimental and control class, by computing the students' individual scores in the posttest minus the students' individual scores in the pretest to both experimental and control class. After obtaining the deviation score to both classes, the researcher counted the mean deviation of the score. Having counted the mean deviation, then the researcher computed the square deviation by computing the score deviation $\left(\mathrm{d}^{2}\right)$ minus by the result of the deviation to both experimental and control class.
Furthermore, the researcher computed and analyzed the data in order to know the significant difference between pretest and posttest to both experimental and control class.

Based on the data, the highest score of posttest in the experimental class is 100 and the lowest score was 20 . The mean score of posttest in experimental class is effectively improved from 1060 to 1940 . Finally, the result shows that the using short movies as a media inn teaching learning process can improve speaking ability at the eleventh grade students of SMA Negeri 5 Palu.

The successfulness of this media was because the students and the teacher interacted each other. The students lost their nervous of speaking. It means that the discussion of the material after watching short movies that related to the material can minimize the students' ashamed in active of speaking. Many practice than exercises improved students' fluency and accuracy in speaking.

The researcher has proven that using short movies as a media in teaching is effective in improving speaking ability at the eleventh grade students of SMA Negeri 5 Palu, the result of his research $t_{\text {counted }}$ (6.48) is higher than $t_{\text {table }}(2.002)$, it means that the researcher hypothesis is accepted.

\section{Conclusion And suggestions}

The researcher concludes that using short movies as a media in teaching improves speaking ability at the eleventh grade students of SMA Negeri 5 Palu. Based on the result of data analysis shows by comparing $t_{\text {counted }}$ and $t_{\text {table, where the }}$ researcher found that $t_{\text {counted }}(6.48)$ is higher than $t_{\text {table }}(2.002)$. it can be proved by the result of the students' pretest and posttest of the experimental class. Before the treatment, the mean of the pretest of the experimental class is 1060 , while the mean 
of the posttest of the control class is 1150 . After giving the treatment, the mean of the posttest of the experimental class 1940 while the mean of the posttest of the control class just 1490. There is a significant difference of the mean between the pretest and posttest of the experimental class. The result indicates that the mean of the posttest and after the treatment using short movies as a media is better than the mean of the pretest. So, short movies can improve speaking ability at the eleventh grade students of SMA Negeri 5 Palu.

After getting the result of this research and concerning to the conclusion above, the researcher would like to provide some suggestions that might be important for the improvement in the teaching learning process. Short movies can be used as a media in teaching speaking in senior high school. First, for the students is the opportunity for them to come and stand in front of the class and learn with their friends. When the students learn together with their friends, it encouraged the students to learn from each other. Second, the teacher suggested try teaching English by using various media not only focus on method or technique, or they can try to use media in applying their technique to the students. Third, for the researcher, it may better to find another effective ways to use short movies as a media in teaching. And the last for the school, the school should complete the facilities to learn English such as kind of games and equipment for teaching ad learning English, especially in learning speaking skill such as LCD, speaker, electricity distribution, etc.

\section{Bibliography}

Arikunto, S. Prosedur penelitian suatu pendekatan praktek (Edisi RevisiVI). Jakarta: PT Rineke Cipta, 2006.
Best, W.J., and Kahn, V.J. Research in Education (Tenth Edition). United States of America: Pearson Education Inc, 2006.

Brown, H Douglas. Principles of Language Learning and Teaching, Fourth Edition. White Plains. NY : Pearson Education, 2000.

Language Assessment:

Principles and Classroom Practices NewYork : Pearson Education Inc. Javanovich, 2003.

Chaney. Heinemann English Language Teaching. New York : Cambridge University press, 1998

Depdikbud. Scores Category. Jakarta: Dikti, 1996

Hadi, S. Metodologi Research. Yogyakarta: Yayasan Penerbitan Fakultas Psikologi Univesrtitas Gajah Mada, 1995.

Harmer, J. English language teaching. Pearson Education Limited : Harlow, 2001. . How to Teach English. China:

Pearson Education, 2007.

Heaton, J.B. Writing English Language Test. Hongkong: Longman Group, 1998.

John, Gebahrdt. Using Movie Trailers in a ESL Call Class. Japan: Ritsumeikan University, 2004

Kalaen, Imayati. Speaking Skill Improvement By Using Movie As Media. Malang: Unisma, 2013.

Kayi, L. The nature of language in use. Bandung. Tritustra, 2006.

Lynch, M. L. 5 Ways to Use Popular Movies for English Language

Teaching. Ezine Articles, (http://EzineArticles.com/?expert= Larry M. Lynch), 2006.

Munadi, Y. Media Pembelajaran: Sebuah Pendekataan Baru. Jakarta: Gaung Persada Press, 2012 


Media
(Yogyakarta:
2008),

Norma, prayogi. Improving Students' Speaking Ability By Using Cartoon

Film. Surabaya : State University of Surabaya, 2013.

Nunan, D., \& Carter, R. (Eds.). The Cambridge guide to teaching English to speakers of other languages. Cambridge: Cambridge University Press, 2001.

Nurdin, N. (2009). Segregasi Dalam Pengajaran Dan Penguasaan Bahasa. MUSAWA, 1(1), 23-41.
Richard, J.C. Teaching Listening and Speaking : From Theory to Practice. New York: Cambridge University Press, 2008.

Sudjana, N., \& Rivai, A. Media Pembelajaran. Bandung: Sinar Baru Bandung, 1992.

Thornburry, S. How to Teach Speaking. Harlow, England: Longman, 2005.

Yatimah, Durotul. The effectiveness of using animation film as the medium in writing narrative text. Salatiga : STAIN Salatiga, 2014. 